Маја J. МЕДАН*

Универзитет у Новом Саду

Филозофски факултет
Оригинални научни рад

Примљен: 05. 11. 2016.

Прихваћен: 10. 02. 2017.

\title{
ОД НЕМИЛА ДО НЕДРАГА МИЛАНА ДЕДИНЦА: ЕСЕЈИЗАЦИЈА ЛИРСКЕ ПРОЗЕ ИЛИ ЛИРИЗАЦИЈА ЕСЕЈА
}

\begin{abstract}
„Али пред зору, преко свих губера, убити треба
Песника; да не потеже личност своју из детињства:

Као случајни, замршени, канап из хлеба

Ким неће нахранити никада себе, као ни зверства!"

(Р. Петровић, „Откровење”, Ово о једном песнику)
\end{abstract}

Милан Дединац је у свој аутопоетички избор из поезије Од немила до недрага (1957) поред песничких текстова укључио и наглашено лиризоване есеје који су у функцији паратекстуалне апаратуре. Примарни циљ овог рада јесте анализа песниковог предговора и пропратних есеја, којом би се утврдио њихов статус у односу на саме песничке текстове. Привидно паратекстуална апаратура нема квалитет секундарног, изведеног текста у односу на примарни текст поезије, него се својим семантичко-синтаксичким структурама укључује у раван разумевања саме поезије. У последњем делу рада, посебна пажња биће посвећена збирци Мртве рукавице Риста Ратковића, која својом логиком одговара Дединчевим приређивачким решењима.

Кључне речи: Милан Дединац, Ристо Ратковић, есеј, лирика, симболизам, надреализам, аутопоетичко.

Милан Дединац, песник који је припадао надреалистичком покрету, али је у важним поетичким опредељењима напуштао оквире надреализма и окретао се симболистичким решењима, комплексност своје песничке позиције изразио је и избором из своје поезије Од немила до недрага (1957). Овај аутопоетички избор садржи, поред песничких текстова, изразито лиризоване есеје који су у функцији паратекстуалне апаратуре: најпре опширан предговор, а затим и низ уводних текстова којима се евоцира атмосфера стварања сваке од седам песничких целина. Иако наизглед само теже реконструисању стварносних околности које су условиле карактер песама, ови есеји пред-

*medanmaja@gmail.com 
стављају интегрални део у драматургији датог стваралачког опуса Милана Дединца. У међуодносу есеја од којих би се очекивало да, у одређеном степену, денотирају песме, и песама од којих би се очекивало да демонстрирају одређене експликације из есеја, не постоји потпуна сагласност: појављује се вишак лирског који традиционални избор из поезије претвара у надреалистички хибридни текст.

Сагледавајући своје песничко дело у целини, после одређене временске дистанце, Дединац покушава да оживи и наизглед прозирним, исповедним тоном објасни „оно што су уствари други написали, други који су некад били $J A$ " (Дединац 1957: 12). Тиме овај избор из поезије има један наглашено аутобиографски и аутопоетички карактер а аутор не само да одређује избор из сопственог песничког опуса него опцртава доминантне координате настајања модерног европског и српског песништва уопште, упућујући на специфичне фазе у стваралаштву Бодлера, Рембоа, Лотреамона, Аполинера, Диса, Ујевића, Црњанског, Растка Петровића, које он сматра релевантним. Мемоарски карактер ове књиге поезије употпуњен је и елементима дневника, што се поред очекиваних дневничких елемената из пропратних есеја, потврђује и песничком целином „Песме из дневника заробљеника број 60211” написаном у немачком логорима у Шлеској за време Другог светског рата. У полиморфну структуру Од немила до недрага укључују се и путописни елементи који се, поред подразумеваних промена географије условљене песниковим путовањима, посебно рефлектују у последњем циклусу, „И зрака и мрака препуне су зене (песнички огледи с путовања по Црној Гори 1939-1955)”. Са циљем да истакну плурализам, када су у питању стратегије читања ове Дединчеве књиге, истраживачи су покушавали жанровски да је одреде и као „лирски роман” (Вучковић 2014), посматрајући је у контексту традиције лирског романа Арагона, Бретона, Ристића, Вуча. Такође, неконвенционалност овог избора провоцирала је и могућности драмског читања, које је било и извођено у Атељеу 212, 1958. године (Ђурић 2014).

Циљ овог рада не укључује потребу за коначним жанровским одређењем Дединчеве књиге, као што не укључује ни питање зашто Дединац изоставља одређене песничке текстове који припадају његовим модернистичим почецима, те на који начин се то уклапа у контекст књижевних политика педесетих година прошлога века. ${ }^{1}$ Примарни циљ овог рада јесте анализа песниковог предговора и пропратних есеја којом би се утврдио њихов статус у односу на саме песничке текстове: привидно паратекстуална апаратура нема квалитет секундарног, изведеног текста у односу на примарни текст поезије, него се својим семантичко-синтаксичким структурама укључује у раван разумевања саме поезије, обезбеђујући специфичну хронологију дешавања целокупне Дединчеве књиге. Ова међузависност пропратних текстова и поезије обезбеђена је на најмање два различита начина: најпре, у предговору, Дединац

\footnotetext{
${ }^{1}$ Биљана Андоновска, у раду „Ако се још једном сетим: књижевно памћење и збирка-опус Од немила до недрага М. Дединца” (2014) сагледава Дединчеву збирку у контексту издавачке политике Нолита средином педесетих година. Такође, у опширно истраживање укључује и Дединчеве потиснуте најраније песничке и прозне радове.
} 
разграђујући традиционалну форму есеја понавља оне песничке поступке, као и лирску слику света, на којој је некада заснивао своје песништво, чиме упућује на дубљи дијалошки однос паратекста и текста; и друго, на тематско-мотивском плану, генеза одређених, готово сталних мотива у Дединчевој поезији не само да се може пратити од његове прве укључене збирке, Зорило и Ноћило певају, него отпочиње односно накнадно се успоставља у самом предговору, који је последњи написан.

Уколико бисмо упоредили позицију субјекта у предговору Од немила до недрага са, рецимо, позицијом субјекта у неким Дединчевим поемама као што су „Ноћна врачања” или „Јавна птица”, уочили бисмо симптоматичну блискост. Питање идентитета, свест о многострукости бића који су изражени кроз дисхармонично вишегласје „Јавне птице” или „Шлеске рапсодије” обнавља се и у предговору, Дединчевим контроверзним односом према некадашњим ,jа”. Млади песник/млади песници призивају се као нека врста двојника, чиме се умножава и, мање вртоглаво него у поемама али ипак динамично, мења перспектива приповедача:

И онда ко да порекне право усамљеном младићу на тргу и његовом двојнику, ономе мом далеком ЈА кога је однела прошлост и чији лик, ево, узалуд покушавам, у ноћи, да осветлим неједнаком светлошћу свога памћења, ко да им оспори право да, у великој љубави према Рембоу, на сва питања која траже објашњења његових необјашњивих поступака и његовог дела, одговарају упорно - ћутањем? (Дединац 1957: 30).

Дединац тако, већ у предговору, формирајући фигуру двојника као једну од важних фигура његовог целокупног песништва, започиње игру умножавања идентитета коју ће касније, кроз већ написане песме, варирати на различите начине. Тако ће располућеност субјекта и удвостручавање његове свести, рецимо, у „Ноћним врачањима”, бити изражено кроз имплицитан мотив повампирења:

На распаљеном гробу, у мрчави овој, без жеђи, разлили смо по небу сва вина, пробдили, испили за собом крваве реке до краја... Где ми је сан?

То нико не зна. Ја сам у два смеха извукао ногу из гроба [...]

$\mathrm{O}$, ја сам, ја сам...Зову ме за пластом Анна, а овде - ax, друго име хоћу (Дединац 1957: 115).

Други варијетет ове фигуре умножавања бића, Дединац ће, на пример, остварити у „Песмама из дневника заробљеника број 60211”. У свету редефинисаном ратом, песник преузма на себе улогу народног певача, покушавајући да, до тада изразито субјективан глас, замени колективним гласом свих заточеника Шлеских логора:

То прво лице, то смо ти и ја, друже, и сви другови наши из ропских логора Шлеске. А редови ови, ове припросте песме престају да буду моје, постају наше. Или ничије [...] Ако ли ко од другова мојих прочита икад стихове ма које моје песме, па ред само један или реч једна зацвили или кликне у њему, нека зна да је тај стих, да је та реч његова била и да сам је ја само ишчупао из његових груди, а сад му је, ето, враћам (Дединац 1957 : 194).

Поменута тема двојника, којом Дединац започиње ову књигу поезије, везује се за два психичка феномена: „или је реч о удвојеној, односно душев- 
но располућеној личности са проблемом идентитета, или се удвојеношћу демонстрира конфликт између инстинктивног дела личности који је присиљен да се противно својим жељама повинује друштвеним нормама" (Радин 1996: 135-136). Борбу између пасивизованог субјекта и инстинктивног дела личности, као и потребу да се та борба фиксира, текстуализује, Дединац такође уписује у свој предговор, свестан да ће тиме остварити још једно подударање са надолазећим, а већ написаним песмама. Дихотомија: пасивни субјект/ослобођена жеља, у предговору има свој израз у пару: Дединац писац пропратних текстова/Дединац аутор песама, односно, огледа се управо у несразмери, немогућности да се из позиције у којој се приређује књига Од немила до недрага Дединац врати у онај имагинативни, духовни, стваралачки оквир из којег је као младић писао песме. Таква борба пасивног субјекта и ослобођене жеље која увек резултира немогућношћу да се у потпуности овлада подручјем жеље, у овом случају некадашњом инспирацијом, аналогна је и немогућности да се, у поеми „Јавна птица”, освоји подручје ероса, био он везан за драматику песничког стварања, или за неосвојивост и неухватљивост жељене птице-девојке. Тако у оба случаја, али и у великом броју других песама, песник пише из стања незадовољства, из некакве недостатности која је изражена честим вапајем, узвиком посве херметичних стихова, који се као важан предсказивачки елемент, атипично, појављују још у пропратним текстовима.

Ако погледамо на који начин је у предговору наратор-песник смештен у простор у којем интроспекцијом треба да поврати оно заувек изгубљено, приметићемо да он већ у самом уводу своје аутопоетичке књиге има потребу да читаоца суптилно адаптира на специфичан однос лирског субјекта и какофоничног окружења, који ће се касније појављивати у одабраним поемама, нарочито у (анти)поеми „Јавна птица”. Изолован у затвореном простору, док напољу бесни олуја (атмосфера подсећа на поему „Један човек на прозору”), песник осећа да „бруји моја соба-шкољка као да чува јауке свих ветрова овога света” (Дединац 1957: 17). Соба, која је „болнички гола”, „кула његових авети”, тесна, хладна, туђинска, хоће да га одвоји од сећања, хоће ,јаву у сан да ми преруши" (Исто: 50), у варку, у несећање. Ипак, песник успева да произведе многогласност, сазвучје унутар собе-шкољке, дозивајући мноштво напуштених, бивших ,jа" и њихових нарација. Овај поступак писања пропратних текстова у којима треба објаснити сопствену поетику, својом логиком недвосмислено подсећа на саме сцене песничког стварања о којима говори Дединац: „Често ми се чинило да су песме, моје песме, уствари најчешће пука дозивања. И да на крају кад застану, заћуте, то је једино зато да би осушнуле ехо” (Исто: 52). У „Јавној птици”, такође, „,[с]убјект покушава да се постави у центар песме, да сагледа релације свега у односу на себе, отуда се и у његовом говору све управља ка првом лицу”. „Све што изговара као да се попут одјека враћа, али изобличено. Однос се успоставља пре свега између сопства у једном и сопства у неком другом тренутку, јер је у њему све оно што 'птица' значи присутно у већој или мањој мери" (Веселиновић 2014:303). Тако у предговору наратор каже „замном се, огромна, моја сенка надвила” (Дединац 1957: 17), док у „Јавној птици” читамо: 


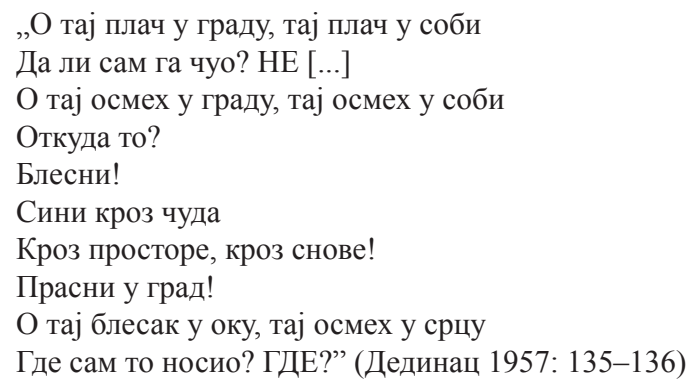

Јасно је да соба као простор одјека и укрштања симултаног присуства прошлости, не дозвољава хармонизацију искуства, ни у тексту, ни у паратексту, а истоветност анализираних релација још једном потврђује да Дединац, пишући свој предговор, није имао за циљ да наивно објасни свој песнички поступак, него да га укорени, поново, у лирски амбијент, приближавајући га ипак за један корак ближе у правцу стварности, постварењ $а$ - на начин на који су то захтевали авангардисти.

Као што смо већ раније назначили, померање значаја и функције пропратних текстова у оквиру аутопоетичког избора Од немила до недрага, Дединац не остварује само преношењем његових већ познатих и добро разрађених песничких поступака и аутентичне слике света у подручје есеја ${ }^{2}$, него и свесним стварањем прото-мотива из којих ће се касније, кроз драматургију целе књиге, развити Дединчеви готово стални мотиви у својој комплексној симболици. Ово упућује на чињеницу да, упркос тенденцијама надреалистичке фрагментарности, код Дединца готово ништа није произвољно, те се са сигурношћу може говорити о хомогеној, интегралној структури целокупног његовог опуса - док пропратни текстови дају коначан оквир и смисао том континуитету. Важно је истаћи и да је начином на који је организовао избор из сопственог стваралаштва, Дединац указао на финалну промену парадигме, која је супротстављена његовим младалачким опредељењима. Наиме, пишући о песничкој младости, аутор неретко доводи у питање исправност самих термина „песник” и „песме”, истичући антикњижевну и антиуметничку усмереност својих надреалистичких почетака. Песме као „ефемерне творевине духа, настале у једном тренутку и писане за један тренутак” (Дединац 1957: 19) неретко су третиране као „непотребни отпаци” који се не намењују литератури нити било каквој потреби архивирања. Овај антиестетски надреалистички став Дединац пориче не само чињеницом да је пристао да направи канон сопственог дела и објави два избора из поезије (Од немила до недрага из 1957. и Позив на путовање из 1965. године) него, још више, својом намером да унутар тог дела успостави одређени каузалитет, фабуларност, одго-

\footnotetext{
2 Лингвостилистичком анализом пропратних текстова Милана Дединца лако се може установити понављање оних семантичко-синтаксичких решења које користи и у својим поемама. Ту пре свега мислимо на поступке интонационог и позиционог издвајања реченичних чланова (поступак парцелације реченице), а затим и на друге стилске механизме којима се постиже реченична експресивност (експресивна сегментација реченице, различити поступци интензивирања исказа). Више о томе у раду: Медан 2015: 149-171.
} 
варајући тако на симболистичке, малармеанске захтеве за стварањем једне свеобухватне књиге.

Овом приликом, са циљем објашњења поменуте фабуларности, усмерићемо се само на одабрани мотив птице, који свакако представља један од најважнијих мотива Дединчевог песничког опуса. ${ }^{3}$ Аутор, без нужне потребе, мотив птице у њеном одсуству поставља на почетак другог фрагмента, другог дела предговора: „Кошава је очистила небо; а оно - грдно и пусто!... Бар птицу једну да је оставила под куполом од стакла, ташту птицу једину!” (Дединац 1957: 47). Овде се наравно може говорити само о некаквом наслућивању важности присуства/одсуства птица, иако тоналитет реченице својом експресивношћу подсећа на ритам „Јавне птице”. Даље, у циклусу насловљеном „Зорило и ноћило” птица је такође присутна својим одсуством, али на један другачији начин. Ликовима Зорила и Ноћила (који ће се и касније појављивати у другим песничким целинама, па и у самој „Јавној птици”), Дединац упућује на митолошки подтекст чији су елементи видљиви у песмама, али се, наравно, предање не износи у свом потпуном облику који је за нас од кључне важности:

По предању, била су три митска брата: Ноћило, Поноћило и Зорило. Прича се да су браћа дошла до некакве јаме па у њу спустили брата Зорила, који се нађе на другом свету, где пронађе цареве кћери. Зорило, под ударом чаробног бича, претвори једну цареву кћер у златну јабуку и стави је у недра. Браћа извуку из јаме цареве кћери, а Зорила, из пакости, оставе у њој. Зорила из јаме изнесе нека птица. Тако се он опет нађе на овом свету са својом златном јабуком у недрима (СМР 1998: 207-208).

Како се може ишчитати из наведеног предања, птица, која је у овом циклусу индиректно присутна, разрешава драму Зорила који има искуство оног света, пре свега својом способношћу да делује у подручју граничног, лиминалног простора. Тако се већ овде, имплицитно, за мотив птице везује трансгресивни карактер - она има способност напуштања света материјалности и комуникације са оностраним.

Наведена семантика птице потврђује се али и додатно усложњава у поеми „Ноћна врачања”. Као мото трећег дела поеме појављује се народна пословица: „Благо мјесту отклен оде, а тешко ономе у које иде”, а читав део тематизује народно веровање да але једу сунце и „кад але коначно успеју да поједу Сунце, биће то смак света (Зечевић 1981: 62-74)”: „Алуштина је Она / и напаст је, и ала/ ала је отрована! / И несита је ала / јер Сунце ждере, јер ми је изјела руке: / око њеног паса" (Дединац 1957: 117). Да не би ала успела да поједе сунце, ,људи пуцају из пушака према помрачењу, лупају у клепетала и звона, а жене непрестано бају” (СМР 1998: 6): „Па лупај! Зато лупај у тигањ и тепсије! / Удари у сва звона / да оде Она / та гладна, / да оде та гладна ала / јер ће нам појести Сунце” (Дединац 1957: 116). Аналогно предању о Зорилу, и овде сунце спасава птица која ,уместо сламке, један камичак Сунца у кљуну носи" (Дединац 1957: 118). Међутим, у наставку поеме суочавамо се са

\footnotetext{
${ }^{3}$ Генеза сталних мотива у песништву Милана Дединца захтева посебно истраживање/а, а у постојећој литератури ова проблематика је само делимично исцрпљена.
} 
карактеристичном надреалистичком трансфигурацијом, изједначавањем, најпре птице и сунца: „Горе, на модрој пучини неба, светлуца. Птица” (Дединац 1957: 118), а затим и але и девојке, која тако постаје средишњи семантички склоп око којег се окупљају сви делови ове поеме. Комплексним односима између различитих идентитета у поеми „Ноћна врачања” (лирски субјекат постаје вампир; ала једе сунце; птица се идентификује са сунцем; ала постаје девојка; вампир се слади девојачком крвљу - поема се завршава стихом: „Из Сунца изгрева дан /...ДАН ЊЕНЕ КРВИ КОЈА МЕ, ЈУТРОС, ЗАЛИВА...”), Дединац већ овде мотив птице доводи у јасну везу са мотивом девојке (попут утве златокриле из наше наредно поезије), што ће амплифицирати и радикално продубити у поеми „Јавна птица”. Тако код Дединца, од наслућивања али обавезног помињања у предговору, преко постепене изградње полисемичности кроз варирање унутар различитих циклуса, птица се, са својом пуном симболиком, тек у „Јавној птици” коначно проглашава главним ликом овог Дединчевог „интелектуалног романа” (Лукић 1972: 8).

Установљено нарушавање традиционалне разлике између паратекста и текста у овом Дединчевом избору могло би да се упореди са ипак радикалнијим стратегијама подривања које песник Ристо Ратковић остварује у свој збирци-плакети Мртве рукавице (1927). ${ }^{4}$ Не само да је упоредив начин конципирања књиге у којем се флуидним кретањем одређених мотива негира вештачки створена поларизација текста на примарни и секундарни него су и појединачне песме у прози засноване на компарабилним елементима. Б. Стојановић Пантовић истиче да ,у поеми Јавна птица статус песме у прози најочигледније сведочи о преливању стиха у исказ, а да се при томе не доводи у питање доминантно песнички карактер и прагматика текста”. „Слично се у српској књижевности може уочити код још једног сапутника надреализма Ристе Ратковића, у збирци Мртве рукавице, односно поеми Левиатан из 1927. године” (Стојановић Пантовић 2014: 261-262). У наставку рада покушаћемо да анализирамо могућности овог поређења.

Најпре, Ристо Ратковић можда најсугестивнији део своје плакете Мртве рукавице означава као предговор, чије границе у тексту нису јасно распознатљиве - предговор је писан истом логиком, ритмом и стилом као и остатак збирке тако да се не може са сигурношћу тврдити шта то обезбеђује укидање гласа песника и успостављање гласа песме. Предговор у Мртвим рукавицุама, нарочито у прозним пасажима, има функцију дидаскалија којима се уоквирује време/простор и неретко потцртава доминатни мотивски план који ће касније на различите начине бити вариран - слично као и у Дединчевим пропратним текстовима. Ова дидаскалична проза свакако доприноси перформативности оба текста који добијају квалитет драмског дешавања, упот-

\footnotetext{
${ }^{4}$ Намеће се питање који је смисао поређења избора из поезије једног аутора са збирком песама у прози (или плакетом) другог аутора, нарочито уколико се има у виду да је и Ристо Ратковић објавио сопствени избор из поезије, који би се можда нудио као боље решење. Међутим, Ратковићеви Додири (1952) представљају један конвенционални избор из поезије који његове надреалистичке песме ставља у други план.
} 
пуњеног различитим мотоима, посветама (код Риста Ратковића Монију де Булију, Кости Атанасијевићу), писмима, коментарима.

Већ на самом почетку предговора за Мртве рукавице песнички субјект доводи у питање ауторство сопствених стихова. Стихове заправо овде приређује/тка/певуши фантом-баба, а песнички субјект истиче да су „многи од тих стихова били некада предвиђени за ову књигу а сад ми се чини да их је боље цитирати онако како их је употребила фантом-баба" (Ратковић 1927: 6). ${ }^{5}$ Као и код Дединца који константно инсистира на дискрепанцији између аутора песама и аутора предговора, и овде стихови и јесу и нису дело песничког субјекта, који на различите начине покушава да се дистанцира у односу на сопствени песнички глас.

Ова несагласност са самим собом код оба аутора упућује на то да постоји нека Другост која измиче, и која тако не дозвољава да се поврати замишљена, идеална целовитост. Код Ратковића та Другост изражена је мотивима мртве жене, мртве сестре и мртвог оца, док код Дединца она представља немогућност линеарног, уређеног сећања, обновивих многоструких идентитета младог песника: „Премажи руком још очи моје, нека те целу видим и нека твоје мртве рукавице учине чудо на столу" (Ратковић 1927: 14). Тако Ратковићево бдење са руком мртве жене у својој руци одговара Дединчевом покушају писања одавно већ мртвом руком свог некадашњег ЈА. Оно у чему се ова два аутора разликују је начин на који се покушава надокнадити поменута празнина и одсутност. Док се Ратковић отвара према фантазији, Дединац недостатак покушава измирити и директним позивањем на оне песнике који су за њега представљали ауторитете и у којима се предосећани субјект-песник појављује, али, наравно, опет не у својој целини.

Напоредним постављањем фикционалног (које је у предговору обично изражено стихом) и (псеудо)фактографског (које је обично изражено прозом, а код Дединца претпоставља и историјске и биографске чињенице, а касније и исечке из новина), Ратковић и Дединац иронизују поступак контрапунктирања симболичне представе и животног податка. То поништавање раскорака између поезије и живота код Дединца се јавља и као врховни принцип организације целокупне књиге Од немила до недрага, тиме што се пропратни текстови који имају изражен карактер фактографије супротстављају фикционалним песничким текстовима. Овим Дединац остварује рембоовски захтев на који га је упућивао Растко Петровић, а то је да треба ићи за оним светом „где се поезија и живот толико прожимају да се изневеравањем поезије изневерава живот, а прљањем живота прља поезија" (Дединац 1957: 36). Бенјамин у том контексту користи појам „профаног озарења” који одговара Дединчевој основној приређивачкој интенцији:

Svako ozbiljno ispitivanje okultnih, nadrealističkih, fantasmagoričkih talenata i fenomena ima za pretpostavku dijalektičko ukrštanje, koje romantična glava nikada neće moći usvojiti.

Ослањање на бајалачку традицију, као важан аспект лирског народног песништва, заједничко је Ристи Ратковићу и Милану Дединцу. Ипак, Дединац је у том смислу ближи оној традицији језикотворства којој припадају Ђ. М. Кодер, С. Винавер, М. Настасијевић, Д. Благојевић, А. Вукадиновић. 
Nećemo, naime, otići dalje ako patetično ili fanatično podvlačimo zagonetnu stranu zagonetnog; naprotiv prodrećemo u tajnu samo utoliko ukoliko je otkrivamo u svakodnevici, zahvaljujući dijalektičkom načinu gledanja, koji svakodnevicu shvata kao nepronicljivu, nepronicljivost kao svakodnevnu (Бенјамин 1974: 271).

Занимљиво је да се и код Ратковића и код Дединца наслућује нека врста разочарања у реч, слику, па чак и културу, и то баш онда када постоји проблем у постварељу песништва. Код Ратковића постоји известан зазор „од културе, од философије, од књижевности, пуног разочараности и огорчења зато што култура није живот већ само једно средство његово" (Константиновић 1983: 195). Тон којим Дединац пише пропратне текстове, у којима посебно истиче оне ауторе који су на крају,изневерили песнике у себи” (Лотреамон, Рембо, Растко Петровић), носи са собом сличну скепсу по питању (не)делатности поезије: „Реч- „звезда”! О, кад би знала , бар као тама, да зрачи! О, јадна! / Реч „камен”, понекад, за облацима узлеће. / Речи које од чаме нису никад оболеле / и нису никад никог ни мрзеле ни волеле" (Дединац 1957: 16).

Свакако, фиксирајући процесуалност сопственог писања, Дединац је оваквим приступом приређивању удовољио још једном пориву, а то је, да га је увек „више привлачило оно што претходи једној уметничкој творевини но крајњи резултат" (Дединац 1957: 67). Есејизацијом лирске прозе, као и лиризацијом есеја, Дединац овом књигом поезије дописује своје надреалистичке текстове, покушајем бележења иницијатичког дневника једног песничког стварања.

\section{ЛИТЕРАТУРА}

Андоновска 2014: Б. Андоновска, Ако се још једном сетим: књижевно памћење и збирка-опус Од немила до недрага М. Дединца, у: Светлана Шеатовић Димитријевић, Слађана Јаћимовић (ред.), Поезија и поетика Милана Дединца, Београд: Институт за књижевност и уметност, 169-203.

Бенјамин 1974: V. Benjamin, Eseji, prev. Milan Tabaković, Beograd: Nolit.

Веселиновић 2014: С. Веселиновић, Компулзивност и комуникација у Јавној птици Милана Дединца, у: С. Шеатовић Димитријевић, С. Јаћимовић (ред.), Поезија и поетика Милана Дединияа, Београд: Институт за књижевност и уметност, 297-312.

Вучковић 2014: Р. Вучковић, Лирски роман Милана Дединца, у: С. Шеатовић Димитријевић, С. Јаћимовић (ред.), Поезија и поетика Милана Дединияа, Београд: Институт за књижевност и уметност, 43-54.

Дединац 1957: M. Dedinac, Od nemila do nedraga, Beograd: Nolit.

Ђурић 2014: М. Ђурић, Елементи драмског у поезији и поетици Милана Дединца, у: С. Шеатовић Димитријевић, С. Јаћимовић (ред.), Поезија и поетика Милана Дединйа, Београд: Институт за књижевност и уметност, 567-587. 
Елијаде 1980: M. Elijade, Sveto i profano, (prev.) Zoran Stojanović, Vrnjačka Banja: Zamak kulture.

Зечевић 1981: С. Зечевић, Митска бића српских предања, Београд: „Вук Караџић”.

Константиновић 1983: R. Konstantinović, Biće i jezik, Beograd: 1983.

Лукић 1972: С. Лукић, Дело Милана Дединца, у: Милан Дединац, Ноћ дужа од снова, Нови Сад - Београд: Матица српска - Српска књижевна задруга.

Медан 2015: М. Медан, Интонационо и позиционо издвајање реченичних делова у поемама М. Дединца, у: Прилози проучавању језика, Одсек за српски језик и лингвистику Филозофског факултета, 149-171.

Радин 1996: А. Радин, Мотив вампира у миту и књижевности. Београд: Просвета.

Ратковић 1927: Р. Ратковић, Мртве рукавице, Београд: Заштита.

СМР 1998: Српски митолошки речник, Енциклопедијски речник, (пр.) Шпиро Кулишић, Петар Ж. Петровић, Никола Пантелић, Београд: Етнографски институт САНУ.

Стојановић Пантовић 2014: Б. Стојановић Пантовић, Јавна птица Милана Дединца и дискурс песме у прози, у: С. Шеатовић Димитријевић, С. Јаћимовић (ред.), Поезија и поетика Милана Дединца, Београд: Институт за књижевност и уметност, 251-263.

Maja J. Medan

OD NEMILA DO NEDRAGA BY MILAN DEDINAC: ESSAYS IN POETIC PROSE OR POETRY IN ESSAYS

(Summary)

Milan Dedinac in his autopoetic selection of poetry Od nemila do nedraga (1957), in addition to poems, included lyric essays in function of the paratextual apparatus: first, an extensive foreword, then a series of introductory texts that evokes the atmosphere of the creation of each of the seven poetic entirety. The aim of this paper is to analyze the complex interrelationships among essays which somewhat denote poems and poems that demonstrate essays. In the last part of the paper, the analysis will be joined by a collection of poetry Mrtve rukavice by Risto Ratković. 